Gut, 1973, 14, 390-392

\title{
Rectal hyperpolarization following intestinal bypass for obesity
}

\author{
J. RASK-MADSEN ${ }^{1}$, P. BRIX JENSEN, AND J. O. LUND \\ From the Medical Department F and the Department of Clinical Physiology, Glostrup Hospital, \\ Glostrup, Denmark
}

SUMMARY The electrical potential difference across the rectal mucosa in six shunt-operated women was compared with that obtained in 26 normal females. The potential difference was considerably increased in all the patients, whereas the plasma concentrations and the transmural fluxes of sodium, chloride, and potassium were within normal ranges. Based on measurements of plasma renin and plasma aldosterone concentrations in three of the patients, the possibility of secondary hyperaldosteronism could be ruled out.

Intestinal bypass for obesity is followed by frequent diarrhoeas, which are probably caused in part by the action of bile salts on the colonic epithelium (Hofmann, 1967). It seemed of interest, therefore, to investigate whether the transmural potential difference generated by rectal mucosa (Geall, Spencer, and Phillips, 1969; Dalmark, 1970; Edmonds and Godfrey, 1970) would reflect the recently reported changes in colonic absorptive capacity induced by bile acids (Mekhjian, Phillips, and Hofmann, 1971). In addition to measurements of the rectal potential difference, the plasma concentrations of $\mathrm{Na}^{+}$and $\mathrm{K}^{+}$, and the transmural fluxes of electrolytes in six shunt-operated females, we have measured the plasma concentrations of aldosterone and renin in three of the patients, as the potential difference might also be influenced by secondary hyperaldosteronism provoked by sodium depletion (Edmonds, 1967; Edmonds and Richards, 1970), if any, induced by the pronounced loss of faecal fluids.

\section{Patients and Methods}

Six consecutive patients, all females between 20 and 48 years of age, were investigated four to 28 months after intestinal bypass for obesity (preoperative weight 101 to $139 \mathrm{~kg}$ ). All had an end-to-side jejuno-ileostomy, the anastomosis being established

${ }^{1}$ Requests for reprints should be addressed to J.R.-M., Medical Department F, Glostrup Hospital, DK-2600 Glostrup, Denmark.

Received for publication 8 February 1972. between jejunum $37 \mathrm{~cm}$ distally to the ligament of Treitz and ileum $10 \mathrm{~cm}$ proximally to the junction of the ileum with the colon. The patients were in a good general condition at the time of the investigation, and so were the 26 normal females, who comprised healthy volunteers and patients in a medical ward without any recognized disease of the large bowel, liver, kidneys, or circulatory system. None of the controls or the patients studied received corticosteroids, diuretics, or lithium salts. A single patient (case 4) had been treated with cholestyramine (Cuemid) for a fortnight two months before the investigation, and another patient (case 1) was currently being treated with digoxin for auricular fibrillation. The individual weight loss obtained by the patients so far, as well as the number of daily bowel movements, are given in the table. Measurements of the transmural potential difference were performed in all patients postoperatively, and in a single patient (case 6) preoperatively as well. Blood samples were obtained simultaneously with the potential difference after about half an hour of rest for determination of sodium, potassium, aldosterone, and renin in plasma. The experimental nature of the investigation was explained to all patients.

The transmural potential difference was measured at sigmoidoscopy by a modification of the method previously described (Rask-Madsen, Baastrup, and Schwartz, 1972) connecting one of two balanced calomel half-cells (Radiometer, Copenhagen) directly to the negative input of the recorder (Servogor S-RE 541, Goerz Electro, Vienna, internal resistance $10^{8} \mathrm{ohm}$, measuring current $<10^{-7} \mathrm{Amp}$ ) and to a 


\begin{tabular}{|c|c|c|c|c|c|c|c|c|c|c|c|c|c|}
\hline \multirow[t]{2}{*}{ Case } & \multirow{2}{*}{$\begin{array}{l}\text { Months } \\
\text { after } \\
\text { Opera- } \\
\text { tion }\end{array}$} & \multirow{2}{*}{$\begin{array}{l}\text { Total } \\
\text { Weight } \\
\text { Loss } \\
(\mathrm{kg})\end{array}$} & \multirow{2}{*}{$\begin{array}{l}\text { No. of } \\
\text { Bowel } \\
\text { Move- } \\
\text { ments } \\
\text { Daily }\end{array}$} & \multirow{2}{*}{$\begin{array}{l}P D \\
(m V)\end{array}$} & \multicolumn{4}{|c|}{ Concentration in Plasma } & \multicolumn{5}{|c|}{ Transmural Electrolyte Flux (n-equiv $\left.\times \min ^{-1} \times \mathrm{cm}^{-2}\right)$} \\
\hline & & & & & $\begin{array}{l}\mathrm{Na}^{+} \\
\mathrm{m}- \\
\text { equiv/l }\end{array}$ & $\begin{array}{l}K^{+} \\
m- \\
\text { equiv/l }\end{array}$ & $\begin{array}{l}\text { Aldo- } \\
\text { sterone } \\
(\mathrm{ng} / 100 \\
\mathrm{ml})\end{array}$ & $\begin{array}{l}\text { Renin } \\
(\mu g / m l)\end{array}$ & $\begin{array}{l}\mathrm{Na}^{+} \\
\mathrm{Net}\end{array}$ & $\begin{array}{l}\mathrm{Na}^{+} \text {out } \\
\text { of Lumen }\end{array}$ & $\begin{array}{l}\mathrm{Na}^{+} \\
\text {into } \\
\text { Lumen }\end{array}$ & $\begin{array}{c}\mathrm{Cl}^{-} \\
\mathrm{Net}\end{array}$ & $\mathrm{K}^{+} \mathrm{Net}$ \\
\hline $\begin{array}{l}1 \\
2 \\
3 \\
4 \\
5 \\
6\end{array}$ & $\begin{array}{r}28 \\
15 \\
9 \\
9 \\
7 \\
4\end{array}$ & $\begin{array}{l}37 \\
50 \\
15 \\
31 \\
42 \\
14\end{array}$ & $\begin{array}{l}5-6 \\
1-2 \\
5-6 \\
2-7 \\
6-8 \\
5-6\end{array}$ & $\begin{array}{l}-65 \\
-65 \\
-67 \\
-80 \\
-55 \\
-69^{1}\end{array}$ & $\begin{array}{l}143 \\
142 \\
142 \\
139 \\
140 \\
142\end{array}$ & $\begin{array}{l}3 \cdot 6 \\
4 \cdot 0 \\
3 \cdot 8 \\
3 \cdot 8 \\
4 \cdot 3 \\
4 \cdot 2\end{array}$ & $\begin{array}{r}-\overline{4} \\
<1.1 \\
\overline{3.5}\end{array}$ & $\begin{array}{l}- \\
\overline{31} \\
\frac{11}{9}\end{array}$ & $\begin{array}{l}\overline{176} \\
\overline{241} \\
175 \\
254\end{array}$ & $\begin{array}{l}\overline{232} \\
\overline{343} \\
316 \\
299\end{array}$ & $\begin{array}{c}- \\
56 \\
102 \\
141 \\
45\end{array}$ & $\begin{array}{l}\overline{208} \\
\overline{249} \\
236 \\
298\end{array}$ & $\begin{array}{l}-53 \\
- \\
-175 \\
-140 \\
-130\end{array}$ \\
\hline $\begin{array}{l}\text { Healthy } \\
\text { subjects }\end{array}$ & $\begin{array}{l}\text { mean } \pm S \\
\text { range }\end{array}$ & & & $\begin{array}{l}-46 \pm 3 \\
(-41)-(-55)\end{array}$ & 134-144 & $3 \cdot 6-4 \cdot 8$ & $3-18$ & $6-60$ & $238 \pm 111$ & $308 \pm 120$ & $70 \pm 49$ & $283 \pm 99$ & $-141 \pm 70$ \\
\hline
\end{tabular}

Table I Clinical data and values of the potential difference across the rectal wall, the transmural electrolyte fluxes, and concentrations of sodium, potassium, aldosterone, and renin in plasma of six shunt-operated females compared with the corresponding values obtained in normal subjects

${ }^{1}$ Transmural PD was $-47 \mathrm{mV}$ before operation.

vein of the forearm via a $154 \mathrm{mM} \mathrm{NaCl}$ salt bridge, whereas the other half-cell connected the positive input of the recorder with the exploring $\mathrm{KCl}$ salt bridge. The terminal porous plug of the $\mathrm{KCl}$ salt bridge was placed directly on the mucosa via the sigmoidoscope at various distances from the anus, and the transmural potential difference was continuously traced by the recorder.

The method of dialysis of faeces (Wrong, MetcalfeGibson, Morrison, $\mathrm{Ng}$, and Howard, 1965) in vivo adapted for absorption studies by Edmonds (1971) was used for the estimation of transmural electrolyte fluxes. The composition of the solution in the dialysis tubes used to measure the electrolyte movements was $0.9 \% \mathrm{NaCl}$ containing tracer doses of ${ }^{22} \mathrm{Na}$. Concentrations of sodium and potassium were measured by flame photometry, whereas chloride was determined colorimetrically (Schales and Schales, 1941). The ${ }^{22} \mathrm{Na}$ activity (approximately $0.5 \mu \mathrm{Ci}{ }^{22} \mathrm{Na}$ per litre) was measured in a sodium iodide well scintillation counter. Plasma renin concentrations were obtained by the method of Giese, Jørgensen, Nielsen, Lund, and Munck (1970), and plasma aldosterone was measured by radioimmunoassay. The original method of Mayes, Furuyama, Kern, and Nugent (1970) was slightly modified, as separation of free and bound aldosterone was performed by gel centrifugation.

Statistical analysis for the $p$ values was by a twotailed Wilcoxon test for two samples (Wilcoxon and Wilcox, 1964). The values of the potential difference and electrolyte fluxes in the controls are means \pm SD.

\section{Results}

The individual values for the transmural potential difference in shunt-operated patients as well as the mean values of the controls based on measurements in 26 healthy females are given in the table. The values in the patient group were significantly greater than those of the controls $(\mathrm{p}<0.001)$, and there was no overlap. The magnitude of the potential difference appears to be independent of the weight loss and the time elapsing since the operation. The values for sodium and potassium concentrations in plasma were within the normal ranges, and so were the rates for sodium, chloride, and potassium fluxes across the rectal wall (SD based on 17 normal individuals Rask-Madsen and Jensen, 1973). Also the rates for bidirectional sodium fluxes were insignificantly different from those of normal subjects (Rask-Madsen and Jensen, 1973).

When measured, the plasma renin concentration was within the normal range. Plasma aldosterone was found to be subnormal in one case, and in the lower part of the normal range in the remaining two cases.

\section{Discussion}

The most interesting feature in the results of the present study is the pronounced augmentation of the transmural potential difference. The reason for the observed changes of mucosal polarization is unclear, but local changes in the molecular configuration of the mucosal membranes or their enzymes, induced by the surface active bile acids, as well as hormonal factors might be involved.

After the intestinal bypass described above, bile acid absorption by the ileum is reduced, and more bile acids reach the colon producing diarrhoea (Hofmann, 1967). Mekhjian et al (1971) tested human bile acids for their influence on electrolyte absorption in the human colon, and found that 
dihydroxy bile acids inhibit absorption of sodium, chloride, and potassium, or even induce reversible secretion of these ions dependent on the concentration. In rabbit ileum it has been shown also that sodium influx across the mucosal border is inhibited by exposure of the mucosal surface to bile salts (Frizzell and Schultz, 1970). However, inhibition of sodium absorption, which is believed to be the source of the transmural potential difference in colon (Cooperstein and Brockman, 1959; Curran and Schwartz, 1960; Grady, Duhamel, and Moore, 1970), should predictably reduce this potential difference. Our results for transmural electrolyte flux measurements showed no significant alterations from normal. Secretion of chloride, which might result in great negative potentials, did not occur.

Aithough frequent diarrhoeas involving loss of water with the faecal fluids may lead to increased release of vasopressin, it has been demonstrated (Levitan and Mauer, 1968) that this hormone administered intravenously causes a decrease in colonic net sodium absorption. The possibility of secondary hyperaldosteronism, which is a known cause of increased potential difference across the human rectal mucosa (Edmonds and Richards, 1970), has been excluded by the simultaneous measurement of plasma aldosterone and plasma renin concentrations in three out of six cases. For the time being we can, consequently, give no explanation for the rectal hyperolarization found in all patients studied. Prospective investigations of electrolyte metabolism and electrical polarization in response to intestinal bypass for obesity are in progress.

This investigation was supported by grants from the Danish Medical Research Council, the Novo Foundation, and King Christian X Foundation. We wish to thank Professor Michael Schwartz for his suggestion that the transmural potential difference should be measured in these patients.

References

Cooperstein, I. L., and Brockman, S. K. (1959). The electrical poten- tial difference generated by the large intestine: its relation to electrolyte and water transfer. J. clin. Invest., 34, 435-442.

Curran, P. F., and Schwartz, G. F. (1960). Na, Cl, and water transport by rat colon. J. gen. Physiol., 43, 555-571.

Dalmark, M. (1970). The transmucosal electrical potential difference of rectum in the unanesthetized man. Scand. J. Gastroent., $5,277-282$.

Edmonds, C. J. (1967). The gradient of electrical potential difference and of sodium and potassium of the gut contents along the caecum and colon of normal and sodium depleted rats. J. Physiol. (Lond.), 193, 571-588.

Edmonds, C. J. (1971). Absorption of sodium and water by human rectum measured by a dialysis method. Gut, 12, 356-362.

Edmonds, C. J., and Godfrey, R. C. (1970). Measurement of electrical potentials of the human rectum and pelvic colon in normal and aldosterone-treated patients. Gut, 11, 330-337.

Edmonds, C. J., and Richards, P. (1970). Measurement of rectal electrical potential difference as an instant screening-test for hyperaldosteronism. Lancet, 2, 624-627.

Frizzell, R. A., and Schultz, S. G. (1970). Effect of bile salts on transport across brush border of rabbit ileum. Biochim. biophys. Acta (Amst.), 211, 589-592.

Geall, M. G., Spencer, R. J., and Phillips, S. F. (1969). Transmural electrical potential difference of the human colon. Gut, 10, 921-923.

Giese, J., Jørgensen, M., Nielsen, M. D., Lund, J. O., and Munck, O. (1970). Plasma renin concentration measured by use of radioimmunoassay for angiotensin I. Scand. J. clin. Lab. Invest., 26, 355-367.

Grady, G. F., Duhamel, R. C., and Moore, E. W. (1970). Active transport of sodium by human colon in vitro. Gastroenterology, $59,583-588$.

Hofmann, A. F. (1967). The syndrome of ileal disease and the broken enterohepatic circulation: cholerheic enteropathy. Gastroenterology, 52, 752-757.

Levitan, R., and Mauer, I. (1968). Effect of intravenous anti-diuretic hormone administration on salt and water absorption from the human colon. J. Lab. clin. Med., 72, 739-746.

Mayes, D., Furuyama, S., Kem, D. C., and Nugent, C. A. (1970). A radioimmunoassay for plasma aldosterone. J. clin. Endocr., 30, 682-685.

Mekhjian, H. S., Phillips, S. F., and Hofmann, A. F. (1971). Colonic secretion of water and electrolytes induced by bile acids: Perfusion studies in man. J. clin. Invest., 50, 1569-1577.

Rask-Madsen, J., Baastrup, P. C., and Schwartz, M. (1972). Lithiuminduced hyperpolarization of the human rectum in vivo. Brit. med. J., 1, 496-498.

Rask-Madsen, J., and Jensen, P. B. (1973). Electrolyte transport capacity and electrical potentials across the normal and the inflamed human rectum in vivo. Scand. J. Gastroent., in press.

Schales, O., and Schales, S. S. (1941). A simple and accurate method for the determination of chloride in biological fluids. J. biol. Chem., 140, 879-884.

Wilcoxon, F., and Wilcox, P. A. (1964). In Some Rapid Approximate Statistical Procedures. Lederle Laboratories Division, American Cyanamid Co., Pearl River, New York,

Wrong, O., Metcalfe-Gibson, A., Morrison, R. B. I., Ng, S. T., and Howard, A. V. (1965). In vivo dialysis of faeces as a method of stool analysis. I. Technique and results in normal subjects. Clin. Sci., 28, 357-375. 